\title{
Introducing Gender Perspective in Darussalam Islamic Boarding School
}

\author{
Yuyun Sunesti \\ Department of Sociology Universitas Sebelas Maret (UNS) \\ Surakarta, Indonesia \\ yuyun_sunesti@staff.uns.ac.id
}

\author{
Argyo Demartoto \\ Department of Sociology Universitas Sebelas Maret (UNS) \\ Surakarta, Indonesia
}

\begin{abstract}
The study of gender and Islamic boarding school, which is known well as pesantren has been numerous. The scholarly research showed the efforts of introducing gender awareness as well as the challenges. This paper aims to discus one of the challenges in introducing gender values through the pesantren's education in Pesantren Darussalam Banyuwangi, the challenges faced and the efforts taken. This research is a qualitative research applying in depth interview and participant observation to collect the data. The research sample is purposive sampling, the data are analyzed through interactive model and they are validated by triangulation source. The research findings confirm the students' gender biased perception and several strategies used by the nyai through formal education in classes as well as informal education out of classes with limited support from the surrounding. This research is significant to find more suitable methods to promote gender awareness in pesantren without attracting conflict within the pesantren members and traditions.
\end{abstract}

Keywords-gender, pesantren, young female leader, challenges, strategies

\section{INTRODUCTION}

Pesantren is an educational institution with Islamic religion as a specific academic course. Dhofier [1] pointed out five basic elements of the pesantren, which are: pondok (a religious boarding school under the direction of a kyai), masjid (the mosque as a place for training students), kitab kuning (for teaching classical Islamic texts, particularly of the Shafi'ite school), santri (male and female students), and kyai (a male leader, often founder, of a pesantren). Pesantren can be classified into two important categories: (a) Pesantren Salafi, which preserve the teaching of classical Islamic texts as essential education, and (b) Pesantren Khalafi, which has either introduced the teaching of secular subjects or incorporated secular schools.

The growth of pesantren khalafi in the late of this century has changed the educational system of pesantren which previously focused on the traditional system of education into more modern system. Many more pesantren recently has incorporated their Islamic contents of education and secular materials through the development of either Islamic public school as well as Islamic private school under the Ministry of Religious Affairs. Thus, in today's pesantren, students can access not only Islamic materials but also secular subjects so that they can continue their further education to any higher Islamic or secular schools. However, not all 'secular' ideas have been accepted to introduce to students, one of them is gender ideas.

This paper focuses on the effort of a pesantren Darussalam member, a young female leader of pesantren known well as nyai, in introducing an idea of gender equality in pesantren in her limited power and spaces. Pesantren Darussalam located in Banyuwangi East Java, which operates the khalafi educational system. This pesantren offers students the comprehensive formal educational system from the kindergarten to university level and combining secular and madrasah teaching system. Yet, the ideas of gender have been challenged to grow as the perspectives dominated in pesantren are gender-biased [2]. The centrality of kyai as leader, policy-maker and interpreter of Islam as well as kitab kuning (classical Islamic texts) as well as the monologue transmission of the knowledge have been argued having significant influences in supporting patriarchal culture which have been targeted by feminist criticism [3]. Although some Islamic organizations as well as Muslim feminists has started to introduce gender awareness to pesantren, Kholifah [4] argues that the resistance and endeavors of pesantren leader in preserving their traditions. Thus, this paper uses the pesantren terminology as a whole of modern-formal education offered within the pesantren as well as informal education meaning the classical-traditional subjects taught within it. In this paper, the formal education is represented by IAIDA (Institut Agama Islam Darussalam), a small university under Pesantren Darussalam and the informal education is outside IAIDA teaching activities within pesantren Darussalam.

\section{LITERATURE REVIEW}

The study of gender and pesantren has confirmed the importance of introducing gender awareness to the pesantren students (santri) as Marhumah [5] argues that their perspective of male and female relationship has dominated by Islamic classical textbooks which is mostly gender biased. She also states that the central role of kyai having Islamic textual interpretative domination has been also the problem of gender awareness raising within the pesantren. Therefore, the reinterpretation of classical texts is needed to encourage greater gender equality in pesantren.

One of the informants coming from pesantren family tended to promote gender awareness by legitimating it with Islamic holy books such as Quran and Hadith as well as doing re-interpretation to Islamic classical books. 
In her research, Khariroh [6] also emphasizes the roles of faith-based feminism within pesantren acting as agent of change in facing patriarchal repression derived from cultural practices and gender-biased religious interpretation. By looking at two pesantrens in Java, which are Pesantren Darut Tauhid and Pesantren Cipasung in Tasikmalaya, she argues that the involvement of pesantren elites in promoting gender as these two pesantren have done could become a model for the effectiveness of gender awareness program. In these two pesantren, the pesantren elites has been the first people to internalize this gender perspective which then they spread this awareness to their students and their pesantren networking. This elite's gender awareness cannot be apart from their open minded thought to discuss the new issues around the Islamic discourses as well as their interaction with the Muslim feminist networkings outside pesantren.

In different focus, the discussion on gender and pesantren was also flourished by the discussion of Towaf [7] as well as Sciortino, Natsir and Mas'udi [8] by focusing on young pesantren students and their sexuality problems. As the sexuality has become the common issue for young people, they recommend the need of sexual reproduction health education to be introduced to students of pesantren beside of gender awareness program. Towaf states that this is due to the exclusive interaction within pesantren leading to the students to have limited experiences in having relationship with different sexes as well as limited information on the sexual reproduction health. The sexual reproduction health will be significant information and guidance for the students to interact with the other sexes in their present and future social interaction. In more rigid discussion on this reproductive health issue, Sciortino, Natsir and Mas'udi evaluates the work of a Moslem NGO called the Indonesian Society for Pesantren and Community Development (P3M) in promoting dialogue on reproductive rights among women in pesantren in rural Java and Madura. They argued that P3M's work is a model for understanding how Islamic religious texts support women rights and women advancement rather than women subjugation.

Thus, the scholars' discussion on gender and pesantren has mostly focusing on the efforts of promoting gender awareness including reproductive health as the sub-topic of gender awareness effort in pesantren through what Khariroh calls faith-based feminism by finding legitimization from Islamic holy books as well as re-interpretation of Islamic classical texts. This is likely because they are regarded as the best strategy in order to gender is accepted peacefully within pesantren tradition--even though still attracting many debates from pesantren conservative members. This research has been slightly similar in looking at how gender awareness movement has been initiated by the pesantren members who have direct family relationship with the pesantren elites. However, while those scholars focus on the religious textual re-interpretation, the female leaders of this research in Darussalam pesantren have taken more on the non-Islamic textual re-interpretation efforts.

\section{RESEARCH METHODOLOGY}

The challenges in introducing gender in Pesantren Darussalam in this paper are elaborated through in depth interviews of female leaders of Darussalam pesantren and participant observation within the pesantren everyday life, which had been conducted from July to August 2016. These two methods were conducted to gain comprehensive data in describing the situation and condition of pesantren as well as to what extent the challenges of gender awareness occur in pesantren. The student's work paper is also given and analyzed to look at primarily on how students perceive gender issues around them. For this, the purposive sampling is applied as the sample has been already determined which are the nyais as the female leader of Darussalam Pesantren and the targeted students. The data are analyzed through interactive model which has three level of analysis: data reduction, data display and conclusion [9] and are validated by triangulation method by using multiple data sources to produce understanding. .

This research focuses on Pesantren Darussalam Blokagung Banyuwangi East Java because of several reasons. The first reason is that this pesantren is categorized as an old pesantren as it is founded in 1951 and has thousands students. Another interesting of this pesantren is it located in the remote area of Banyuwangi yet it applies the khalafi model of education, which has enabled pesantren to apply not only traditional system of education but also the modern one. Although in the remote area, this pesantren has the educational system from kindergarten to university level. The second reason is that even though claim as modern, the ideas of modern values such as gender perspective has been challenged to be accepted by pesantren members. The third reason is the fact that there are several female leaders in this pesantren who has progressive thinking, yet they have still challenged with the pesantren tradition. That is why looking at the challenges and strategies taken by the young female leaders in this pesantren is important to enrich the model of empowerment by young female generation of pesantren members.

The center of this research is the leadership of one of Pesantren Darussalam's young generation who is Zulfi Zumala. Zulfi is a ning or young nyai, a call for a daughter of the pesantren owner. She is regarded as the third generation of the pesantren Darussalam members, which at present the second generation has dominated the pesantren elite. Besides actively teaching at pesantren and IAIDA, she is also a member of Fatayat, NU's young women organization, in Banyuwangi and joining Rahima, Muslim women NGO, as a local representative for some gender empowerment programs in Banyuwangi. Because the resistance of the pesantren elite in accepting ideas of gender, she has been trying to introduce gender values through several strategies. Even though the leadership of Zulfi is being the focus of this research, the interview is also supported by the other female leaders in her pesantren family.

To get to know the perspective of female and male students in perceiving a gender understanding, the student work group in Zulfi's class is operated. There are ten groups of about forty female students and thirty male students in her classes and asked them different topics relating to gender. These female 
and male students are in the second semester and most of them were in their fourth year in pesantren and in average 19 and 20 years old. The eight questions around the gender roles are questioned to know to what extent the students understand as well as perceive gender in their daily life. The questions are discussed in the groups and the answers are written as a summary on a paper.

The data are analyzed by comparing the perception given by male and female students to understand the tendencies of the students in perceiving gender based on their current understanding. The data coming from the interview are important to look at the strategies taken by Zulfi especially and the young female Darussalam leaders generally in order to disseminate gender values to their students in particular and pesantren community in general.

\section{RESULTS AND DISCUSSIONS}

The challenges in introducing gender in pesantren Darussalam occur both in formal and informal education. Zulfi argues that the challenges mostly come from the biased gender perspectives of kyai in perceiving unequal position between men and women. For example of this is seeing women to should have good attitude especially in following their husband's will when they have married. The challenges also come from the resistance of pesantren elites, kyais, in accepting the new ideas of modernism especially the idea of liberalism, which they assume that gender is a part of this idea, which is far from Islamic values. Therefore, she has difficulties to just share their knowledge on gender ideas, which she believe is accordance with Islamic values to santri moreover to kyai and nyai. The one flexibility to express this is only through her class in the university as well as the community library which she is responsible to. Zulfi uses soft strategies to introduce gender values by avoiding direct confrontation with pesantren traditions. She argues that direct confrontation is not effective and the consequence will bring her off from the teaching duties in pesantren as well as in the university.

The questions on gender are delivered to the students to understand to what extent the idea of gender has been known and perceived by them. The results confirmed that most students, both male and female students, argue than men and women have different roles as men have higher position than women. The answers below from one of female student group describe this view:

"Men an women have big rules but man is leader of woman" (group 7 in answering the question of gender role in Islam in their perspectives)

"Always obey to her husband, knowing what should they do to make him happy and love her. Love family, good cooking, caring for her children, hate to hang out without husband's permission, smile everyday, but also not dependent to her husband, good for having a job but not forgetting with her obligation as a wife at home" (group 1 in answering the question of a good wife according to them)

The similar answer given by the male student group in perceiving gender role as the comments below:
"We do not agree with female leader, because if women become a leader, the country will not be good. Because the soul of the leader is on the soul of men" (group 5 in responding the question of woman as leader)

"She does not have to be pretty, but caring for her family and at the same time independent" (group 1 in answering the question of a good wife in their opinions)

Although represented by few groups of students in the Darussalam pesantren, Zulfi argues that this perspective can be a representative of the mainstream understanding of gender in this pesantren. The fact that the female students have similar opportunity to gain high education in this pesantren cannot be ignored proven by the increase of the female students continuing their higher education in IAIDA as well as regarded as a significant progressive development in the last few years of the pesantren. However, she underlines that this equal educational access has gone outbalance with the gender understanding on the gender daily life issues such as the issue of leadership in pesantren, sharing roles between man and woman in family as well as the perception on woman as a source of moral problem in society.

An example of this is what Nihayah, Zulfi's big sister, said that female preacher cannot be accepted to give speech in front of pesantren members in a big event such as the pesantren's anniversary celebration where female and male pesantren members gather together. The female preacher is allowed to give a speech in front of female audiences. In contrast, male preacher is allowed to give a speech in front of both male and female audiences. She also point outs that indeed, female members of pesantren or nyais are included in the structural members of pesantren as well as are accommodated their opinions, but the decision on the issues discussed in the pesantren is in male leader or kyais.

Zulfi also reveals the challenges as she states that the curricula of the pesantren must be finally agreed by the kyais. Therefore, introducing gender in pesantren curricula is almost impossible at the moment. However, Zulfi also argues that not all kyais forbid gender values to be introduced in pesantren. Kyai Mudhofar, her father, is known as moderate kyai in this pesantren. He supports all his daughters initiated including this gender promotion efforts. Unfortunately, because he is only son in law in this pesantren generation, he has no power and strategic position like the direct pesantren offspring, so that his voice cannot change the situation if the pesantren elites has disagreed with his arguments.

These challenges of promoting gender awareness have confirmed what Marhumah underlines that the centrality of kyai as an interpreter of Islamic classical textbooks as well as having highest position in pesantren has challenged the gender awareness promotion in pesantren. The resistance of what they called 'western agenda' has also making gender more difficult to be introduced for pesantren members as Kholifah underlines which is often claiming to preserve Islamic tradition. Different with what Pesantren Darut Tauhid and pesantren Cipasung Tasikmalaya did which gender awareness has come firstly to the pesantren elites, the initiation of promoting gender awareness in pesantren Darussalam comes from the bottom 
level of pesantren family members who are the third generation of pesantren who have limited access to strategic policy making within pesantren. Therefore, the effort of those young female leaders of pesantren Darussalam has been much harder to realize.

Following this pesantren condition and considering that is impossible for creating a gender topic for the pesantren as well as IAIDA curriculum, Zulfi and her sister make several strategies to introduce gender for pesantren community. In IAIDA, Zulfi gives students articles discussing gender roles for her English Reading class followed by class discussion. Through this method, she can insert gender ideas to the students. Some students are totally rejecting the idea of gender equality she shared; some students can accept that after several discussions in the class. The progress has been fantastic as the rejection groups can slowly interested to proposing further discussion.

Introducing gender values through the class are, she argues, not enough due to limited time, which her English classes are just once a week. Therefore, further soft strategy she and her sister make is through adding a gender book collection in their community library, which is addressed for pesantren community as well as people outside pesantren. This community library was her and her sister initiation due to the limited new and progressive book collections especially in discussing gender perspective both in pesantren and university libraries. This is because the collections should be available in these both places are controlled by pesantren as well as the university elites so that introducing new and progressive Islamic thoughts through these libraries are almost impossible. Therefore, as her community library has grown significantly with increasing readers both from pesantren and outside pesantren, she believes that the dissemination of gender values and the development of gender awareness among pesantren members will be increasing significantly. .

The third strategy is building networking with Islamic gender organizations outside pesantren. Some Islamic women Non-Government Organizations have some women empowering programs for pesantren such Rahima, which is based in Jakarta and has many local representatives in many areas throughout Indonesia. Zulfi states that building networking is important to support their knowledge and skill on gender empowerment as well as to keep her spirit to acquaint gender values for her pesantren members. When Rahima had a training program in her area, Zulfi also brought one of her female students to join the training hoping that the student could spread the information she got to their friends in pesantren.

Thus, although having difficulties in disseminating gender values to pesantren community, an initiation of young female pesantren generation of Darussalam has been a great effort to the development of gender understanding in pesantren. Through their soft strategies, gender values can be accepted slowly by pesantren members with very low in attracting conflict within pesantren members and traditions. The support from women organization outside pesantren has been also an important motivation to keep the spirit alive for the gender fighters like Zulfi Zumala and her sister, the young female pesantren inspiring leaders.

\section{CONCLUSION}

Even though facing many challenges and endeavors from the pesantren elites, female leaders of pesantren Darussalam Banyuwangi has consistently struggling to promote gender awareness in the pesantren. Avoiding direct confrontation with the pesantren authoritative, they has developed a soft strategy in introducing gender values by inserting them in English class discussion and student's work group, book collections in her community library as well as making a networking with Muslim feminist organizations. Indeed, this strategy needs a long process to spread and developed to be gender awareness among pesantren members, but as Zulfi said it has been slowly accepted by them. Henceforth, this strategy can be a good model for introducing gender in pesantren education as well as formulating good methods for further educational discussions and policy in pesantren.

\section{ACKNOWLEDGMENT}

The author is sincerely grateful for Zulfi Zumala and her big family as the key informant for her rich and inspiring stories and hospitality during the interview process.

\section{REFERENCES}

[1] Z. Dhofier, The Pesantren tradition: The Role of the Kyai in the Maintenance of Traditional Islam in Java. United States of America: the Program for Southeast Asian Studies, ASU, 1999.

[2] Marhumah, "The roots of gender bias: misogynist hadiths in pesantrens," Indonesian Journal of Islam and Muslim Societies Vol. 5, no. 2, 2015, pp. 283-304

[3] S. Kholifah, "Gendered continuity and change in Javanese Pesantren," unpublished doctoral thesis, College of Arts of Victoria University, 2014.

[4] B.J. Smith and M. Woodward, "De-colonizing Islam and Muslim feminism," in BJ. Smith \& M. Woodward, Gender and Power in Indonesian Islam: Leaders, Feminists, Sufis and Pesantren Selves, New York: Routledge, 2014.

[5] Z. Dhofier, Tradisi Pesantren: Studi Tentang Pandangan Hidup Kyai (The Pesantren Tradition: a Study about the Worldview of Kyai), 5th ed, Jakarta: LP3ES, 1990.

[6] Khariroh, "The women movement in Indonesia's pesantren: negotiating Islam, culture and modernity," unpublished Master's thesis, The Faculty of the Center for international Studies, ohio University.

[7] S.M. Towaf, "A Sexuality and reproductive educational package development with gender perspective and religious approach for youngster in Pesantren," Jurnal Ilmu Pendidikan, Jilid 14, Nomor 3, Oktober 2007, pp. 154-165.

[8] R. Sciortino, L.M. Natsir and M.F. Mas'udi, “Advocacy of reproductive rights in Indonesian pesantren," Reproductive Health Matters, vol. 4, no. 8 , on Fundamentalism, women's empowerment and reproductive rights (Nov. 1996), pp. 86-96.

[9] M.B. Miles and A.M. Huberman, Qualitative Data Analysis: An Expanded Sourcebook, Second Edition, SAGE Publication, 1994 